\title{
Toxicity of environmentally important micropollutants on three trophic levels
}

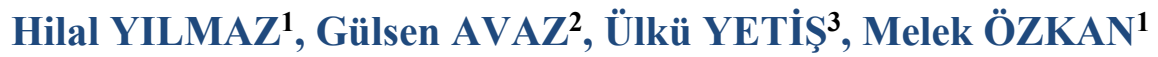

Cite this article as:

Yılmaz, H., AVAZ, G., YETIŞ, Ü., ÖZKAN, M. (2022). Toxity of environmentally important micropollutants on three trophic levels. Aquatic Research, 5(1), 20-28. https://doi.org/10.3153/AR22003

${ }^{1}$ Gebze Technical University, Environmental Engineering Department, 41400 Kocaeli Turkey

2 TUBITAK Marmara Research Center, Institute of Environment and Cleaner Production. 41400 Kocaeli Turkey

${ }^{3}$ Middle East Technical University, Environmental Engineering Department, 06531 Ankara Turkey

ORCID IDs of the author(s):

H.Y. 0000-0002-5782-0283

G.A. 0000-0003-2703-7877

Ü.Y. 0000-0001-7322-0563

M.Ö. 0000-0001-9017-5389

Submitted: 27.01.2021

Revision requested: 11.06 .2021

Last revision received: 18.06 .2021

Accepted: 11.07.2021

Published online: 14.12 .2021

Correspondence:

Melek ÖZKAN

E-mail: mozkan@gtu.edu.tr

\begin{abstract}
Micropollution is a serious environmental problem caused by continuous entry of trace quantities of toxic chemical substances into the aquatic environment. In the present study, three trophic levels of the aquatic ecosystems were used to evaluate the acute toxicities of environmentally important micropollutants including heavy metals, pesticides and drugs. There is a scarcity of information on toxicity of the studied substances on marine water algae. Among studied micropollutants, the most toxic chemical to Daphnia magna and Danio rerio was found to be 1-Chloro-2,4 dinitrobenzene with EC50 of 0.002 and $4.2 \mathrm{mg} / \mathrm{L}$, respectively. Although this compound was also toxic to marine algae, Phaeodactylum tricornutum, arsenic showed the highest toxicity to the algae with EC50 of $2.4 \mathrm{mg} / \mathrm{L}$. As compared to other organisms, D. magna was found to have higher sensitivity to all of the tested micropollutants.
\end{abstract}

Keywords: Aquatic toxicity, Acute toxicity, Micropollutants

Available online at

http://aquatres.scientificwebjournals.com 


\section{Introduction}

Micropollution is an important environmental problem characterized by entry of a wide variety of chemicals into the receiving environments at trace concentrations (ng/L to $\mu \mathrm{g} / \mathrm{L}$ ). Thanks to the resent technological progress in chemical analysis, it is not hard to detect their presence in water (Metz \& Ingold 2014; Hollender et. al. 2007; Schwarzenbach et al. 2006). Continuous input of non-biodegradable, persistent and bioaccumulative micropollutants in receiving waters is an important problem threatening aquatic ecosystem. In spite of their hardly detectable low concentrations in receiving water bodies, most of them raise considerable toxicological concerns (Schwarzenbach et al. 2006). They cause serious pollution issues like poisoning of fish and other aquatic organisms and disturbances in aquatic environment (Shao et al. 2019). Trcilosan which is a widely used biocide can be given as an example to this category. It is frequently detected in different water environments including streams and seawater at concentration ranging from 0.001 to $40.000 \mathrm{ng} / \mathrm{L}$ (SCCS, 2010). This bioaccumulative and persistent chemical has potential negative impacts on human and animal health, it is also highly toxic to green algae, which is an organism having remarkable impact on the balance of the ecosystem (Dhillon et al 2015; Tatarazako et al. 2004). Growth deformities, immunodeficiency, neurobehavioral deficiency and cancer can be listed as important side effects of persistent micropollutants due to bioaccumulation via food chain (Yan et. al. 2018). The feminization of male fish is one of the most striking effect caused by discharge of estrogen containing wastewaters to receiving environments. Being an endocrine disrupting compound it gives harm to the reproductive performance of fish, which leads to disturbances in their population development (Harris et al. 2011).

Global production of anthropogenic chemicals is reported to increase from 1 to 400 million tons per year in the last century (Gavrilescu et al. 2015). It is reported that approximately 280 different micropollutants have been detected in greywater (Etchepare \& Van der Hoek 2015). The source of these compounds reaching receiving environments are mostly human activities such as agriculture, drug and cosmetic industry. Conventional wastewater treatment is reported to be not very effective for removal of micropollutants such as pesticides, industrial chemicals or pharmaceutical products (Wilhelm et al. 2018; Falås et al. 2016; Margot et al. 2015). Because of insufficient treatment, large quantities of micropollutants are dumped into the water environments. It is essential to understand the impact of micropollutants on marine ecosystem and improve treatment technologies for their depollution (Villette et al. 2019).
Study of the toxic effect of environmentally important micropollutants on different aquatic organisms reveals how hazardous they are to the environment and increases knowledge on interactions between test organisms and the chemical substance. Microalgae with their high surface-to-volume ratio can show immediate response to toxic pollutants. Inhibition or enhancement of their growth due to the presence of contaminants provide valuable information about the possible effects of contaminants on the marine-coastal ecosystem. One of the most common standard test organism is the marine diatom Phaeodactylum tricornutum, which is also an important food source for zooplankton and other filter feeding organisms. It is one of the few salt water phytoplanktonic model for toxicity standard tests (Libralato et. al. 2016; Wang \& Zheng 2008). Microalgae, water fleas and zebrafish represent an aquatic food chain as primary producer, primary consumer and secondary consumer, respectively. Being inexpensive, small and easy to care for in large numbers zebrafish is preferred for determination of the water quality and toxic effects of contaminants (Lele \& Krone 1996). It is reported that $70 \%$ of human genes coding for proteins are consistent with zebrafish, and $84 \%$ of these genes are found to be associated with human diseases. Thus, toxicology test results obtained on zebrafish, which is a vertebrate model, can give idea about the effect of toxicants on human health ((Howe et al. 2013; Qian et al. 2018).

In this study, acute toxicity tests for 13 micropollutants including heavy metals, pesticides and drugs were investigated on marine algae, water flea and zebrafish. Among these compounds, polychlorinated biphenyls has great concern. 2,4DCP, a widely used chlorinated phenolic compound for synthesis of agricultural biocides and pharmaceuticals, are a major source of worry for both human and ecological health (Zhang et al. 2018). Heavy metals studied are vanadium, titanium, arsenic and antimony. The chemicals and the potential sectors discharging these micropollutants were listed in Table 1. The micropollutants selected are widely used in our country and have scarce acute toxicity data in literature on marine algae. The other criteria for selection is their $\log \mathrm{K}_{\text {ow }}$ value lower than 3 which results in increased solubility in water. Previously, the Annual Mean Environmental Quality Standards $(\mu \mathrm{g} / \mathrm{L})$ of these micropollutants were determined in a Project on detection of dangerous micropollutants for Turkey coastal and transitional waters. Their bioavailability, annual quantity of usage in the country (import or production) and ecotoxicity were among the important criteria for EQS determination (Tübitak 2017). The extremely hazardous chemical tested in this study with annual mean EQS value of $0.05 \mu \mathrm{g} / \mathrm{L}$ is Azinphos-methyl, which is an organophosphate pesticide. 
EQS values of n-Butyltin Trichloride, Triadimenol and Vanadium are also low so they are regarded to be dangerous with their low mean annual EQS values (1-2 $\mu \mathrm{g} / \mathrm{L})$.

\section{Material and Methods}

\section{Test Compounds}

All the chemicals listed in Table 1 were supplied by Sigma Aldrich. Stock solutions of the micropollutants were prepared in distilled water. EC50 values for each chemical was determined for five different concentrations diluted from their stock solutions.

\section{Toxicity Tests}

Water fleas (Daphnia magna): Water fleas were cultured in a $2 \mathrm{~L}$ beaker containing $1 \mathrm{~L}$ of distilled water and fed with Chlorella vulgaris. The photoperiod was applied as $16 \mathrm{~h} \mathrm{~L}$ and $8 \mathrm{~h} \mathrm{D}$, and the temperature was $20^{\circ} \mathrm{C}$ (Bernot et al. 2005). This culture was used for inoculation $100 \mathrm{~mL}$ of test solution containing toxic chemical of interest. All experiments were initiated with $24 \mathrm{~h}$ old organisms. The animals were not fed during the tests. The test solutions containing required amount of toxic chemicals were prepared by making dilutions from stock solutions in appropriate concentration range. For each concentration, $100 \mathrm{ml}$ of test solutions was prepared in two beakers and 10 Daphnia magna were placed into each beaker and monitored for 96 hours. The measured toxic effect was death of organisms recognized as immobilization for $15 \mathrm{~s}$ after stimulation by a bright light.

Marine algae (Phaeodactylum tricornutum): Microalgae are cultured in vessels containing only nutrient medium (as controls) and nutrient medium to which the test micropollutant is added. The algae cells was cultured in $\mathrm{F} / 2$ medium which contains $75 \mathrm{~g} / \mathrm{L} \quad \mathrm{NaNO}_{3}, 5.65 \mathrm{~g} / \mathrm{L} \quad \mathrm{NaH}_{2} \mathrm{PO}_{4} .2 \mathrm{H}_{2} \mathrm{O}$, $12.9 \mathrm{~g} / \mathrm{L} \quad \mathrm{Na}_{2} \mathrm{SiO}_{3} .5 \mathrm{H}_{2} \mathrm{O}, 0.005 \mathrm{~g} / \mathrm{L} \mathrm{CuSO}_{4} .5 \mathrm{H}_{2} \mathrm{O}, 0.011 \mathrm{~g} / \mathrm{L}$ $\mathrm{ZnSO}_{4} .7 \mathrm{H} 2 \mathrm{O}, \quad 0.005 \mathrm{~g} / \mathrm{L} \quad \mathrm{CoCI}_{2} .6 \mathrm{H}_{2} \mathrm{O}, \quad 0.090 \mathrm{~g} / \mathrm{L}$ $\mathrm{MnCI}_{2} .4 \mathrm{H}_{2} \mathrm{O}, 0.909 \mathrm{~g} / \mathrm{L} \mathrm{FeCI}_{3} .6 \mathrm{H}_{2} \mathrm{O}$ (Guillard 1975). Appropriate volumes of nutrient medium were placed in flasks and algae were then introduced into the flasks and standardized light and temperature conditions are provided. Algae cultivation is carried out with an initial cell density of $10^{6}$ cells $/ \mathrm{mL}$ and the experiment is continued for 96 hours. Algae cells at the logarithmic phase are used for toxicity tests. Experiments were performed in a light-dark cycle for 12 hours with 2000$3000 \mathrm{~lx}$ illumunation, at $21 \pm 2^{\circ} \mathrm{C}, \mathrm{pH} 7.1$ for 12 hours. Data of algae growth during the test are obtained in each day for 96 hours (Sun et al. 2016). The results of the test are calculated as $\%$ effect, based on final versus initial population density.

Table 1. Micropollutants studied and their source of pollution

\begin{tabular}{|l|l|}
\hline Micropollutant Cas No & Industrial usage \\
\hline $\begin{array}{l}\text { 1-Chloro-2,4 dinitrobenzene } \\
\text { 97-00-7 }\end{array}$ & $\begin{array}{l}\text { Detecting and determining nicotinamide adenine dinucleotide (NAD), refrigerant in air } \\
\text { conditioning systems, main toxin in pesticide and herbicide products (Santos } \text { et.al., 2021) }\end{array}$ \\
\hline Azinphos-methyl 86-50-0 & Pesticide, agro-chemical product (Zhang et al., 2019) \\
\hline 2-Amino-4-chlorophenol 95-85-2 & $\begin{array}{l}\text { Industrial gases, chemical fertilizers, nitrogen compounds, paints and varnishes } \\
\text { (NCBI,2021) }\end{array}$ \\
\hline Sulfamethoxazole 723-46-6 & Applied as a bacteriostatic drug (Dirany et al., 2011) \\
\hline n-Butyltin Trichloride 1118-46-3 & Plastic raw materials manufacture, processing and coating of metals (NCBI,2021) \\
\hline 3-Chlorophenol 108-43-0 & Tire treading and reprocessing (Wang et al., 2011) \\
\hline 2,4-Dichlorophenol 120-83-2 & Pesticides, herbicides, and bactericides (Zhou, et al., 2020) \\
\hline Triadimenol 55219-65-3 & Agricultural fungicide (Li et al., 2014) \\
\hline Arsenic 7440-38-2 & $\begin{array}{l}\text { Manufacture of pesticides and other agro-chemical products, construction of ships and float- } \\
\text { ing structures (NCBI,2021) }\end{array}$ \\
\hline Vanadium 7440-62-2 & $\begin{array}{l}\text { Manufacture of industrial gases, chemical fertilizers, nitrogen compounds, paints, plastic } \\
\text { raw materials and steel alloys, battery and superconducting materials (NCBI,2021) }\end{array}$ \\
\hline Titanium 7440-32-6 & Manufacture of plastic bag, bag, sachet, sack, box, carboy, bottle and reel (NCBI,2021) \\
\hline Antimony 7440-36-0 & $\begin{array}{l}\text { Flame-retardants, rubber vulcanization, plastic stabilization, white pigment, textile finish, } \\
\text { glass manufacture, ceramic enamels (Paoletti et al., 2001) }\end{array}$ \\
\hline Iron 7439-89-6 & $\begin{array}{l}\text { Manufacture of basic iron and steel products and ferroalloys, chemical fertilizers and nitro- } \\
\text { gen compounds (NCBI, 2021) }\end{array}$ \\
\hline
\end{tabular}


Zebrafish (Danio rerio): Aerated tap water was used for the preparation of serial concentrations of the chemicals to be tested for toxicity and for the pond containing the Danio rerio. In the experiment, ten Danio rerio were placed in a $2 \mathrm{~L}$ glass beaker containing $1 \mathrm{~L}$ of solution and the fish were monitored for 96 hours after the addition of chemicals. The number of dead fish was recorded every 24 hours (Sun et al. 2016).

\section{Calculation of \%Effect for Micropollutants}

$\%$ effect vs chemical concentration graphics for all the chemicals on three different organisms were given in Suplementary file. \% Effect values are calculated by using following equation

$\%$ Effect $=\frac{\# \text { of death organisms in test }}{\# \text { of alive organisms in control }} \times 100$

\section{Results and Discussion}

In the present study, three trophic levels of the ecosystems including producers ( $P$. tricornutum), primary and secondary consumers (D. magna and D. rerio), were used to evaluate the toxicities of environmentally important micropollutants listed in Table 1. Micropollutants which has rare or no toxicity test results on marine algae were selected for determination of their toxicity. Benthic microalgae play a key role in in biogeochemical cycles and are important for the control of marine resources. Marine organisms living in estuarine and coastal sediments will be the first targets of toxic pollutants. They are exposed to a number of natural and synthetic pollutants, including trace metals, pesticides, various PAHs, biocides, and other pollutants coming from plastic or cosmetic industry (Tato \& Beiras 2019). The toxicity of micropollutants such as PAHs and metals on marine organisms has been widely investigated (Brown et al. 2004; Company et al. 2004; Singh et. al. 2004; Morlon et al. 2005). However, only a few compounds are subject to legal regulations (Rogowska et. al. 2020) and unfortunately large number of contaminants are still discharged into the nearest river or sea without removal from wastewater. Toxic contaminants including most of the micropollutants threat survival of aquatic organisms and disturb marine ecosystem. Drastic changes in the ecosystem may result in difficult-to-reverse circumstances. For example, effect of micropollutants on microbial loop functioning is reported to a cause of mucilage problem in Meditteranean Sea (Danovaro et. al. 2009). To protect marine life, determining the pollutants with high toxicity and characterizing the ecological risk to aquatic organisms is critical. Although prediction tools using quantitative structure activity relationship (QSAR) models such as Ecological Structure Activity Relationships (ECOSAR) can also be applied for risk assesment studies (Li et. al. 2021), data based on ecotoxicological tests is primarily preferred.

Being dominant in most marine ecosystem, the diatom P. tricornutum appears as a good model to study the interactions between toxic contaminants and marine ecosystem (Poirier et al. 2018). Phytoplanktons (microalgae) are the primary producers at the base of the aquatic food chain, so that they are the first targets to be affected by pollution (Satoh et al. 2005). Algae are ecologically important organisms and generally sensitive to test substances. Also algal tests are rapid and cost effective (Arensberg et. al.1995).

Table 2 presents $96 \mathrm{~h}$ acute toxicity test results for $13 \mathrm{mi}-$ cropollutants on three trophic level. EC50 and LC50 values were obtained by measuring the effect of at least five concentrations of the chemical on the test organisms. Graphics for determination of EC50 and LC50 values can be found in the Supplementary file. Figure 1 shows \%effect graphics for the most toxic chemical for each individual test organism. Toxicity experiments on three trophic level revealed that $D$. magna is the most sensitive organism to all of the tested micropollutants except 2,4-Dichlorophenol (Table 2). This substance together with 1-Chloro-2,4 dinitrobenzene showed their highest toxicity to zebrafish (Figure $1 \mathrm{C}$ ). 1-Chloro-2,4 dinitrobenzene, an intermediate solvent used in many sectors, was shown to be highly toxic to all organisms but it was found to be toxic to D. magna the most (Figure $1 \mathrm{~A}$ ). In a previous study, 48h EC50 of 1-Chloro-2,4 dinitrobenzene was reported to be $0.8 \mathrm{mg} / \mathrm{L}$ for Chlorella pyrenoidosa, a freshwater green algae (Maas-Diepeveen \&Leeuwen 1986) and 0.49 $\mathrm{mg} / \mathrm{L}$ for D. magna (Dierickx \& Vanderwielen 1986). In our study, EC50 for D. magna was found to be $0.002 \mathrm{mg} / \mathrm{L}$, much more lower than previous studies. Toxicity of other chlorinated compounds, 2,4-Dichlorophenol and 3-Chlorophenol, were not as high as 1-Chloro-2,4 dinitrobenzene for $D$. magna, however, all the chlorinated compounds including these two were shown to be highly toxic to zebrafish. Toxicity of a chemical substance may differ with respect to the test organism due to the difference in their cell structure and function, and level of organization. Vertebrates possess enzymatic and non-enzymatic antioxidant systems as defense against oxidative stress (Fontagné-Dicharry et al. 2017). There is not much toxicology data for 1-Chloro-2,4 dinitrobenzene for zebrafish in the literature. Some material safety data sheets report LC50 as $0.32 \mathrm{mg} / \mathrm{L}$ for zebrafish, however we have obtained $96 \mathrm{~h} \mathrm{LC50}$ as $4.2 \mathrm{mg} / \mathrm{L}$ for this organism. There is a detailed acute toxicity data for 2,4 dichlorophenol (Moermond \&Heugens 2009) in which LC50 value was given as $3.9 \mathrm{mg} / \mathrm{L}$ for zebrafish for $96 \mathrm{~h}$ (Guillard 1975). We obtained similar EC50 value for 2,4 dichlorophenol for zebrafish. The pesticide, Azinphos-methyl, which is accepted 
as extremely hazardous was found to be highly toxic to $D$. magna with EC50 of $6 \mu \mathrm{g} / \mathrm{L}$ but its toxicity to marine algae is not higher than heavy metals. In the present study D. magna was found to be sensitive to micropollutants more than marine algae.

Table 2. Half-maximal effective concentrations of micropollutants on three trophic levels

\begin{tabular}{|l|l|l|l|}
\hline \multicolumn{1}{|c|}{ Micropollutant } & $\begin{array}{c}\text { Daphnia magna } \\
\text { EC50 }(\mathbf{9 6} \mathbf{~ h )}(\mathbf{m g} / \mathbf{L})\end{array}$ & $\begin{array}{c}\text { P. tricornutum } \\
\text { EC50 }(\mathbf{9 6} \mathbf{~ h})(\mathbf{m g} / \mathbf{L})\end{array}$ & $\begin{array}{c}\text { Danio rerio } \\
\text { LC50 }(\mathbf{9 6 h})(\mathbf{m g} / \mathbf{L})\end{array}$ \\
\hline 2,4-Dichlorophenol & $\underline{17.7}$ & 16.7 & $\mathbf{4 . 2}$ \\
\hline 3-Chlorophenol & 12.3 & 25.5 & 34.1 \\
\hline n-Butyltin Trichloride & 5.8 & 7.9 & 65.6 \\
\hline Iron & 4.0 & 53.7 & $\underline{335.6}$ \\
\hline Sulfamethoxazole & 2.2 & 114.7 & 235.5 \\
\hline Triadimenol & 1.3 & 5.4 & 135.3 \\
\hline Antimony & 0.08 & 4.9 & 103.5 \\
\hline Titanium & 0.055 & 3.7 & 118.4 \\
\hline Vanadium & 0.050 & 6.2 & 124.2 \\
\hline 2-Amino-4-chlorophenol & 0.023 & 65.2 & 5.5 \\
\hline Arsenic & 0.023 & $\mathbf{2 . 4}$ & 21.9 \\
\hline Azinphos-methyl & 0.006 & 8.6 & 11.7 \\
\hline 1-Chloro-2,4 dinitrobenzene & $\mathbf{0 . 0 0 2}$ & 5.2 & $\mathbf{4 . 2}$ \\
\hline
\end{tabular}

Underlined values are the highest, bold ones are the lowest toxic concentrations for a species. Half maximal effective concentration for each chemical were calculated from the equations obtained from \%effect vs concentration graphics (Supplementary file)

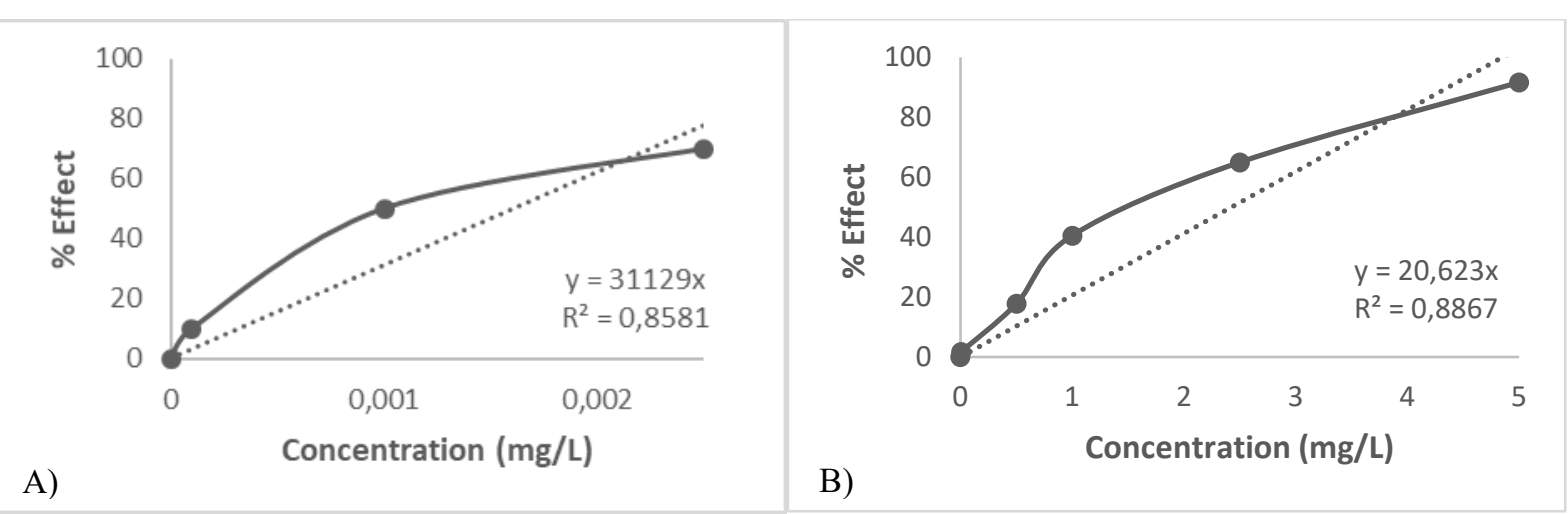

Daphnia magna

Phaeodactylum tricornutum

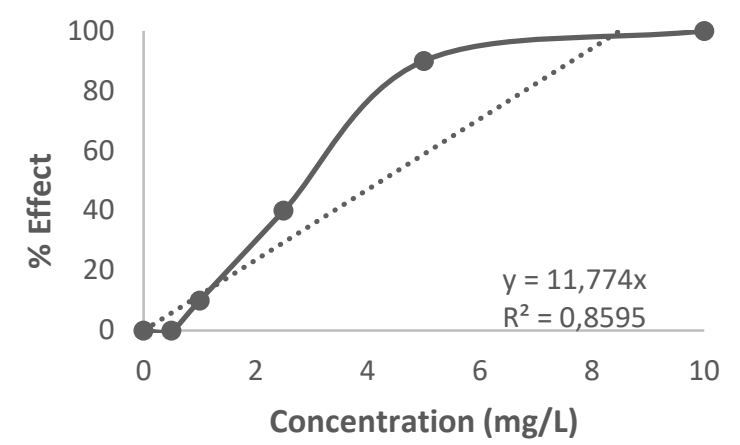

C)

\section{Danio rerio}

Figure 1. \%Effect of the most toxic micropollutants studied on three trophic level A) 1-Chloro-2,4 dinitrobenzene for water flea Daphnia magna, B) Arsenic for marine algae Phaeodactylum tricornutum, and C) 1-Chloro-2,4 dinitrobenzene for zebrafish Danio rerio. 
Heavy metals (e.g., copper, lead, mercury) are one of the most widely used contaminants and serious forms of environmental pollution. Except for iron, studied heavy metals in the present work were determined to be highly toxic for water flea and marine microalgae. As an higher level consumer, zebrafish, is more resistant to heavy metals as compared to the chlorinated organic compounds. Arsenic showed high toxicity to $D$. magna and $P$. tricornutum. Concentrations as low as $23 \mu \mathrm{g} / \mathrm{L}$ was found to be enough to give harm to water fleas. Among the substances examined in this study, arsenic was shown to be the most toxic chemical for microalgae, $P$. tricornutum (Figure $1 \mathrm{~B}$ ). Vanadium also showed remarkable toxicity to $D$. magna and $P$. tricornutum. It was reported that the growth of an aquatic plant is stimulated by trace quantities of vanadium (1-10 $\mu \mathrm{g} / \mathrm{l})$, but concentrations above $100 \mu \mathrm{g} / 1$ are toxic. Power and beat producing industry using fossil fuels (such as petroleum, coal and oil) cause the most widespread discharge of vanadium into the environment (Venkataraman \& Sudha 2005).

\section{Conclusion}

Ecotoxicity of 13 environmentally important micropollutants including heavy metals such as arsenic, titanium and vanadium, pharmaceuticals including sulphametaxazole; industrial solvents used in plastic raw material manufacturing including 2,4-dichlorophenol and n-butyltin trichloride, and chemicals used in pesticide manufacturing like azinphos-methyl were tested on marine water algae, water flea and zebrafish. Although those micropollutants are not priority micropollutants they are hazardous or extremely hazardous substances used in various industries at high quantities. The results of the study showed that water flea, D. magna, is most sensitive organisms to almost all of the micropollutants tested. Among the tested micropollutants, 1-chloro-2,4 dinitrobenzene which is used in paint and agricultural chemical manufacturing industry was found to be the most toxic compound to all tested species. Arsenic and azinphos-methyl were also found to be highly toxic to all the organisms used in this study. Marine microalgae used in this study is shown to be affected remarkably by heavy metals which are one of the major causes of marine pollution in our country.

Result of the study will be useful for validation of environmental quality standards for micropollutants entering marine environment. We dramatically experienced a mucilage problem in Marmara Sea in 2021 and understand how microalgal community change and dominance of harmful species can have devastating results in sea ecosystem. Stress exerted by toxic pollutants on plankton community not only cause death of organisms but also make them increase exopolysaccharide production which turns into mucus at the end. In order to protect marine ecosystem, environmental quality standards should be strictly applied for the micropollutants entering the water bodies from various industries.

\section{Compliance with Ethical Standard}

Conflict of interests: The authors declare that for this article they have no actual, potential or perceived conflict of interests.

Ethics committee approval: Ethics committee approval is not required.

Funding disclosure: We thank Turkish Scientific and Technological Research Council (TUBITAK) for supporting this study (Project No: 115Y025).

Acknowledgments: -

Disclosure: -

\section{References}

Arensberg, P., Hemmingsen, V.H., Nyholm, N. (1995). A Miniscale Algal Toxicity Test. Chemosphere, 30(11), 210315.

https://doi.org/10.1016/0045-6535(95)00090-U

Bernot, R.J., Brueseke, M.A., Evans-White, M.A., Lamberti, G.A. (2005). Acute and Chronic Toxicity of Imidazolium-Based Ionic Liquids on Daphnia Magna. Environmental Toxicology and Chemistry 24(1), 87.

https://doi.org/10.1897/03-635.1

Brown, R.J., Galloway, T.S., Lowe, D., Browne, M.A., Dissanayake, A., Jones, M.B., Depledge, M.H. (2004). Differential Sensitivity of Three Marine Invertebrates to Copper Assessed Using Multiple Biomarkers. Aquatic Toxicology, 66(3), 267-78.

https://doi.org/10.1016/j.aquatox.2003.10.001

Company, R., Serafim, A., Bebianno, M.J., Cosson, R., Shillito, B., Fiala-Médioni, A. (2004). Effect of Cadmium, Copper and Mercury on Antioxidant Enzyme Activities and Lipid Peroxidation in the Gills of the Hydrothermal Vent Mussel Bathymodiolus Azoricus. In Marine Environmental Research, 58, 377-81.

https://doi.org/10.1016/j.marenvres.2004.03.083

Danovaro, R., Fonda, S., Pusceddu, U.A. (2009). Climate change and the potential spreading of marine mucilage and 
microbial pathogens in the Mediterranean Sea. PlosOne, 4(9), e7006.

https://doi.org/10.1371/journal.pone.0007006

Dierickx, P.J., Vanderwielen, C. (1986). Glutathione-Dependent Toxicity of the Algicide 1-Chloro-2,4-Dinitrobenzene to Daphnia Magna straus. Bulletin of Environmental Contamination and Toxicology, 37(1), 629-32.

https://doi.org/10.1007/BF01607814

Dirany, A., Aaron, E., Oturan, S., Sirés, N., Oturan, I., Aaron, J.J. (2011). Study of the toxicity of sulfamethoxazole and its degradation products in water by a bioluminescence method during application of the electro-Fenton treatment. Analytical and Bioanalytical Chemistry, 400(2), 353-360.

https://doi.org/10.1007/s00216-010-4441-x

Dhillon, G.S., Kaur S., Pulicharla, A., Brar S.K., Cledón, M., Verma, M., Surampalli, R.Y. (2015). Triclosan: Current status, occurrence, environmental risks and bioaccumulation potential. Int J Environ Res Public Health, 12(5), 5657-5684.

Etchepare, R., Van der Hoek, J.P. (2015). Health Risk Assessment of Organic Micropollutants in Greywater for Potable Reuse. Water Research, 72 (April), 186-198.

Falås, P., Wick, A., Sandro, C., Habermacher, J., Ternes, T.A., Joss, A. (2016). Tracing the limits of organic micropollutant removal in biological wastewater treatment. Water Research, 95(May), 240-249.

https://doi.org/10.1016/j.watres.2016.03.009

Fontagné-Dicharry, S., Durante, Sadasivam, H.A., C.A., Kaushik, J., Geurden, I. (2017). Parental and early-feeding effects of dietary methionine in rainbow trout (Oncorhynchus mykiss). Aquaculture, 469(February), 16-27.

https://doi.org/10.1016/j.aquaculture.2016.11.039

Gavrilescu, M., Demnerová, K., Aamand, J., Agathos, S., Fava, F. (2015). Emerging pollutants in the environment: Present and future challenges in biomonitoring, ecological risks and bioremediation. New Biotechnology, 32(1), 147-56. https://doi.org/10.1016/j.nbt.2014.01.001
Guillard, R.R.L. (1975). Culture of phytoplankton for feeding marine invertebrates. in culture of marine invertebrate Animals, 29-60. Boston, MA: Springer US. https://doi.org/10.1007/978-1-4615-8714-9_3

Harris, C.A., Hamilton, P.B., Runnalls, T.J., Vinciotti, V., Henshaw, A., Hodgson, D., Coe, T.S., Jobling, S., Charles R.T., Sumpter, J.P. (2011). The consequences of feminization in breeding groups of wild fish. Environmental Health Perspectives, 119(3), 306-311.

https://doi.org/10.1289/ehp.1002555

Hollender, J., Heinz S., McArdell, C.S. (2007). Polar organic micropollutants in the water cycle. in dangerous pollutants (xenobiotics) in urban water cycle. 103-16. Springer Netherlands.

https://doi.org/10.1007/978-1-4020-6795-2_11

Howe, K., Matthew D.C., Torroja, C.F., Torrance, J., Berthelot, C., Muffato, M., Collins, J.E. (2013). The zebrafish reference genome sequence and its relationship to the human genome. Nature, 496(7446), 498-503.

https://doi.org/10.1038/nature12111

Lele, Z., Krone, P.H. (1996). The zebrafish as a model system in developmental, toxicological and transgenic research. Biotechnology Advances. Elsevier Inc.

https://doi.org/10.1016/0734-9750(96)00004-3

Li, Y., Dong, F., Liu, X., Xu, J., Han, Y., Zheng, Y. (2014). Chiral fungicide triadimefon and triadimenol: Stereoselective transformation in greenhouse crops and soil, and toxicity to Daphnia magna. Journal of Hazardous Materials, 265, 115123.

https://doi.org/10.1016/j.jhazmat.2013.11.055

Li, X., Zhang, R., Tian, T., Shang, X., Xu D., Yingying H., Matsuura, N. (2021). Screening and ecological risk of 1200 organic micropollutants in Yangtze Estuary water. Water Research, June, 117341.

https://doi.org/10.1016/j.watres.2021.117341

Libralato, G., Gentile, E., Ghirardini, A.V. (2016). Wastewater effects on Phaeodactylum tricornutum (Bohlin): Setting up a classification system. Ecological Indicators, 60(July), 31-37. 
https://doi.org/10.1016/j.ecolind.2015.06.014

Maas-Diepeveen, J.L., Leeuwen, C.J. (1986). Aquatic Toxicity of Aromatic Nitro Compounds and Anilines to Several Freshwater Species. Laboratory for Ecotoxicology, Institute for Inland Water Management and Waste Water Treatment, Report No. 86-42: 10 p.

Margot, J., Luca Rossi, Barry, D.A., Holliger, C. (2015). A review of the fate of micropollutants in wastewater treatment plants. WIREs Water, 2 (5), 457-487.

https://doi.org/10.1002/wat2.1090

Metz, F., Ingold, K. (2014). Sustainable wastewater management: Is it possible to regulate micropollution in the future by learning from the past? A policy analysis. Sustainability, 6(4), 1992-2012.

https://doi.org/10.3390/su6041992

Moermond, C.T.A., Heugens, E.H.W. (2009). Environmental risk limits for trichlorophenols. Report $601714005 / 2009$.

Morlon, H., Claude, F., Magali, F., Christelle, A., Jacqueline, G.L., Alain, B. (2005). Toxicity of selenite in the unicellular green alga Chlamydomonas reinhardtii: Comparison between effects at the population and sub-cellular level. Aquatic Toxicology, 73(1), 65-78.

https://doi.org/10.1016/j.aquatox.2005.02.007

National Center for Biotechnology Information (2021). PubChem Compound Summary for CID 5359596, Arsenic. Retrieved June 17, 2021 from

https://pubchem.ncbi.nlm.nih.gov/compound

Paoletti, F., Sirini, P., Seifert, H., Vehlow, J. (2001). Fate of antimony in municipal solid waste incineration. Chemosphere, 42(5-7), 533-543.

https://doi.org/10.1016/S0045-6535(00)00225-3

Poirier, I., Marie, P., Lauriane, K., Philippe, H., Arnaud, D., Arash, J., Johana, C., Christelle, C., Gallon, R.K., Bertrand, M. (2018). Toxicological effects of cd se nanocrystals on the marine diatom Phaeodactylum tricornutum: The first mass spectrometry-based proteomic approach. Ecotoxicology and Environmental Safety, 152, 78-90.

https://doi.org/10.1016/j.ecoenv.2018.01.043
Qian, L., Feng, C., Yang, Y., Yuan, L., Suzhen, Q., Wang, C. (2018). Mechanisms of developmental toxicity in zebrafish embryos (Danio rerio) induced by boscalid. Science of the Total Environment, 634, 478-487.

https://doi.org/10.1016/j.scitotenv.2018.04.012

Rogowska, J., Monika, C., Wojciech, R., Lidia, W. (2020). Micropollutants in Treated Wastewater. Ambio. Springer. https://doi.org/10.1007/s13280-019-01219-5

Santos, J.E.L., Gómez, M.A., Moura, D.C. de, CerroLópez, M., Quiroz, M.A., Martínez-Huitle, C.A. (2021). Removal of herbicide 1-chloro-2,4-dinitrobenzene (DNCB) from aqueous solutions by electrochemical oxidation using boron-doped diamond (BDD) and $\mathrm{PbO} 2$ electrodes. Journal of Hazardous Materials, 402, 123850.

https://doi.org/10.1016/j.jhazmat.2020.123850

Satoh, A., Vudikaria, L.Q., Kurano, K., Miyachi, S. (2005). Evaluation of the sensitivity of marine microalgal strains to the heavy metals, $\mathrm{Cu}, \mathrm{As}, \mathrm{Sb}, \mathrm{Pb}$ and $\mathrm{Cd}$. Environment International, 31(5), 713-722.

https://doi.org/10.1016/j.envint.2005.01.001

Schwarzenbach, R.P., Escher, B.I., Fenner, K., Hofstetter, T.B., Johnson, A.J., Gunten, U.V., Wehrli, B. (2006). The challenge of micropollutants in aquatic systems. Science, 313(5790), 1072-1077.

https://doi.org/10.1126/science.1127291

SCCS (Scientific Committee on Consumer Safety) (2010). Opinion on Triclosan (Antimicrobial Resistance) Scientific Committee on Consumer Safety; Luxembourg: 2010. https://ec.europa.eu/health/scientific committees/opinions_layman/triclosan/en/about-triclosan.htm\#29 (accessed:12.12.2021)

Shao, Y., Chen, Z., Hollert, H., Zhou, S., Deutschmann, B., Seiler, T.B. (2019). Toxicity of 10 organic micropollutants and their mixture: Implications for aquatic risk assessment. Science of the Total Environment, 666(May), 12731282.

https://doi.org/10.1016/j.scitotenv.2019.02.047

Singh, A.K., Sharma, L., Mallick, N. (2004). Antioxidative role of nitric oxide on copper toxicity to a chlorophycean 
alga, chlorella. Ecotoxicology and Environmental Safety, 59(2), 223-227.

https://doi.org/10.1016/j.ecoenv.2003.10.009

Sun, H.Q., Du, Y., Zhang, Z.Y., Jiang, W.J., Guo, Y.M., Lu, X.W., Zhang, Y.M., Sun, L.W. (2016). Acute toxicity and ecological risk assessment of benzophenone and N,N-Diethyl-3 Methylbenzamide in personal care products. International Journal of Environmental Research and Public Health, 13(9), 925.

https://doi.org/10.3390/ijerph13090925

Tatarazako, N., Ishibashi, H., Teshima, K., Kishi, K., Arizono, K. (2004). Effects of triclosan on various aquatic organisms. Environmental Sciences: An International Journal of Environmental Physiology and Toxicology, 11(2), 133140 .

Tato, T., Beiras, R. (2019). The use of the marine microalga Tisochrysis lutea (T-Iso) in standard toxicity tests; comparative sensitivity with other test species. Frontiers in Marine Science, 6 (August).

https://doi.org/10.3389/fmars.2019.00488

TUBITAK (2017). Project on Determination of Hazardous Substances in Coastal and Transitional Waters and Ecological Coast Dynamics. Proje No:5128702.

Venkataraman, B.V., Sudha, S. (2005). Vanadium Toxicity. Asian Journal of Experimental Sciences, 19(2), 127134.

Villette, C., Maurer, L., Delecolle, J., Zumsteg, J., Erhardt, J., Heintz, D. (2019). In situ localization of micropollutants and associated stress response in populus Nigra leaves. Environment International, 126(May), 523-532. https://doi.org/10.1016/j.envint.2019.02.066

Wang, L., Zheng, B. (2008). Toxic effects of fluoranthene and copper on marine diatom Phaeodactylum tricornutum. Journal of Environmental Sciences, 20(11), 1363-1372.

https://doi.org/10.1016/S1001-0742(08)62234-2
Wang, X., Pan, J., Guan, W., Dai, J., Zou, X., Yan, Y., Hu, W. (2011). Selective removal of 3-Chlorophenol from aqueous solution using surface molecularly imprinted microspheres. Journal of Chemical \& Engineering Data, 56, 27932801.

https://doi.org/10.1021/je101275e

Wilhelm, S., Jacob, S., Ziegler, M., Köhler, H.Z., Triebskorn, R. (2018). Influence of different wastewater treatment technologies on genotoxicity and dioxin-like toxicity in effluent-exposed fish. Environmental Sciences Europe, $30(25)$.

https://doi.org/10.1186/s12302-018-0154-0

Yan, Z., Yang, H., Dong, H., Ma, B., Sun, H., Pan, T., Jiang, R., Zhou, R., Shen, J., Liu, J., Lu, G. (2018). Occurrence and ecological risk assessment of organic micropollutants in the lower reaches of the Yangtze River, China: A case study of water diversion. Environmental Pollution, 239, 223232.

Zhang, Y., Liu, M., Liu, J., Wang, X., Wang, C., Ai, W., Chen, S., Wang, H. (2018). Combined toxicity of triclosan, 2,4-dichlorophenol and 2,4,6-trichlorophenol to zebrafish (Danio rerio). Environmental Toxicology and Pharmacology, 57, 9-18.

Zhang, H., West, D., Shi, H., Ma, Y., Adams, C., Eichholz, T. (2019). Simultaneous determination of selected trace contaminants in drinking water using solid-phase extraction-high performance liquid chromatography-tandem mass spectrometry. Water, Air, \& Soil Pollution, 230(28).

https://doi.org/10.1007/s11270-018-4066-9

Zhou, Y., Zhang, Y., Hu, X. (2020). Synergistic coupling $\mathrm{Co}_{3} \mathrm{Fe}_{7}$ alloy and $\mathrm{CoFe}_{2} \mathrm{O}_{4}$ spinel for highly efficient removal of 2,4-dichlorophenol by activating peroxymonosulfate. Chemosphere, 242, 125244.

https://doi.org/10.1016/j.chemosphere.2019.125244 